\title{
Changes in Vitamin D Levels According to Age, Gender and Season in the Siirt Province
}

\author{
Siirt Bölgesinde D Vitamini Seviyesinin Yaş, Cinsiyet ve Mevsimlere Göre Değişimi
}

(1) Naci Ömer Alayunt, (1) Osman Özüdoğru*

Siirt University Faculty of Medicine, Department of Medical Biochemistry, Siirt, Turkey

*Siirt Training and Research Hospital, Clinic of Internal Diseases, Siirt, Turkey

\section{Abstract}

Objective: This study aims to determine the 25-hydroxyvitamin D [25(OH)D] profile of the region based on season, age and gender by examining the vitamin D levels of patients who applied to the Siirt Training and Research Hospital from Siirt and neighbouring provinces.

Materials and Methods: [25(OH)D] levels were analysed retrospectively in patients who applied to Siirt Training and Research Hospital. The study included 31,151 patients who were admitted to the hospital. Were included in the study. [25(OH)D] levels were determined according to the age and gender of patients and the seasons of the year. A serum [25(OH)D] level $<12 \mathrm{ng} / \mathrm{mL}$ was considered as serious deficiency, $12-20 \mathrm{ng} / \mathrm{mL}$ mild-to-moderate deficiency, $21-30 \mathrm{ng} / \mathrm{mL}$ insufficiency, $>30 \mathrm{ng} / \mathrm{mL}$ sufficiency.

Results: The average $[25(\mathrm{OH}) \mathrm{D}]$ level in patients aged $0-15$ years $(n=6,166)$ was $20.59 \pm 0.14 \mathrm{ng} / \mathrm{mL}$, in patients aged 16-30 years $(n=10,791)$ it was $15.65 \pm 0.10 \mathrm{ng} / \mathrm{mL}$, in patients aged $31-45$ years $(n=6,649)$ it was $16.28 \pm 0.14 \mathrm{ng} / \mathrm{mL}$, in patients aged $46-60$ years $(n=4,120)$ it was $16.83 \pm 0.23 \mathrm{ng} / \mathrm{mL}$ and in patients ages $61-75$ years $(n=2,597)$ it was $16.03 \pm 0.15 \mathrm{ng} / \mathrm{mL}$.

Conclusion: It has been observed that $[25(\mathrm{OH}) \mathrm{D}]$ level, which is low in winter and spring, is high in summer and autumn when it is exposed to the intense rays of the sun. However, this level is lower than the desired levels in all four seasons. This low level of vitamin $D$ may be related to the absence of almost any vitamin D synthesis in winter and inadequate vitamin D intake associated with foods.

Keywords: Age, gender, seasons, osteoporosis, UV exposure, vitamin D

\section{Öz}

Amaç: Bu çalışmada, Siirt Eğitim ve Araştırma Hastanesi'ne Siirt ve çevre illerden başvuran hastaların D vitamini düzeyleri incelenerek bölgenin the 25-hidroksivitamin D [25(OH)D] profilinin mevsim, yaş ve cinsiyet bazlı değişimlerinin belirlenmesi amaçlanmıştır.

Gereç ve Yöntem: Siirt Eğitim ve Araştırma Hastanesi'ne başvuran [25(OH)D] düzeyleri retrospektif olarak incelenmiştir. Hastaneye başvuran 31.151 hasta çalışmaya dahil edilmiştir. Hastaların yaş, cinsiyet ve mevsimlere göre [25(OH)D] düzeyleri tespit edilmiştir. Serum [25(OH)D] düzeyinin $<12 \mathrm{ng} / \mathrm{mL}$ olması ciddi eksiklik, $12-20 \mathrm{ng} / \mathrm{mL}$ hafif-orta derecede eksiklik, 21-30 ng/mL arası yetersizlik, >30 ng/mL yeterlilik olarak kabul edilmiştir.

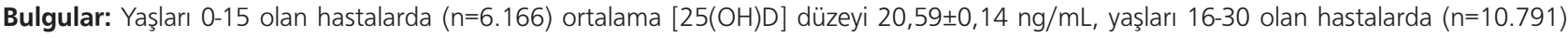

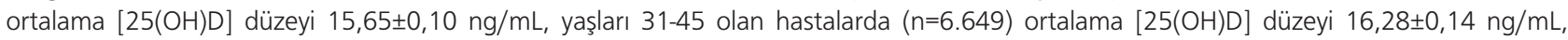

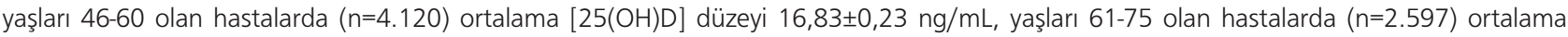

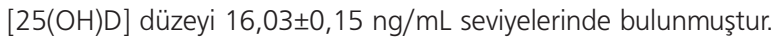

Sonuç: Kış ve ilkbaharda düşük seyreden $[25(\mathrm{OH}) \mathrm{D}]$ güneşin yoğun ışınlarına maruz kalınan yaz ve sonbaharda da yüksek olduğu ancak her dört mevsimde de istenilen düzeylerden düşük olduğu gözlemlenmiştir. D vitamini düzeyindeki bu düşüklük kış mevsiminde hemen hiç vitamin D sentezinin olmaması ve gıdalarla yetersiz D vitamini alımı ile ilişkilendirilebilir.

Anahtar kelimeler: Yaş, cinsiyet, mevsimler, osteoporoz, UV maruziyeti, D vitamini 


\section{Introduction}

Vitamin $D$ is a complex food that is difficult to get used to; it is literally not a vitamin, but a pro-hormone. Even if some of the vitamin $D$ is taken on a diet, its main source is ultraviolet (UV) exposure. Vitamin D is also defined as a steroid-structured vitamin synthesized in the skin along with sunlight (1). Vitamin $D$ has versatile functions beyond calcium homeostasis as well as its traditional role in bone and muscle function (2). Serum 25-hydroxyvitamin D [25(OH)D] levels are considered to be the main circulating forms of vitamin $D$ and represent the body vitamin D status. Vitamin D is a fundamentally critical molecule necessary for the proper functioning of the human body. It plays an important role in musculoskeletal health, as it plays a role in the regulation of calcium and phosphorus. Obesity and chronic non-infectious disease are often clustered, including having a low vitamin D level in the body, osteoporotic stress fractures, and the risk of certain types of cancer and lowering the capacity of the immune system (3-6). In addition to making the sun feel great with its warm effect on the skin, it activates the versatile vitamin $D$ formation that plays a role mainly in our bones, muscles and immune system. It is not always easy to renew vitamin $D$ stores, especially in the winter season. Vitamin $D$ reduces vitamin $D$ stores for various reasons such as tropospheric ozone decreasing vitamin $D$ synthesis in the skin after malnutrition and environmental pollution (7). Today, [25(OH)D] levels lower than $50 \mathrm{nmol} / \mathrm{L}(<20 \mathrm{ng} / \mathrm{mL})$ are defined as deficiency, and 50-75 $\mathrm{nmol} / \mathrm{L}$ (20-30 ng/mL) as deficiency (subclinical deficiency) (8). The preference of $[25(\mathrm{OH}) \mathrm{D}]$ in serum can be explained by its long half-life, showing the storage status of vitamin $D$ in the body, which is taken by diet and synthesized in the skin (9). Interestingly, between the two forms, vitamin $\mathrm{D}_{2}$ and vitamin $\mathrm{D}_{3}$ are metabolized as $[25(\mathrm{OH}) \mathrm{D}]$ in the liver, both of which are biomarkers of vitamin D status (7). Vitamin D deficiency is an important global public health problem, especially among the elderly and closed communities, which contributes significantly to modern health costs, morbidity and mortality.

In this study, it was aimed to determine the $[25(\mathrm{OH}) \mathrm{D}]$ profile of the region based on seasonal, age and gender by examining the vitamin D levels of patients who applied to Siirt Training and Research Hospital from Siirt and neighboring provinces.

\section{Materials and Methods}

The study protocol was approved by the Siirt University Faculty of Medicine Ethics Committee (decision no: 2019/09.03, date: 26.12.2019). In the study, [25(OH)D] levels requested in patients who applied to Siirt Training and Research Hospital between January 2019-January 2020 were retrospectively analyzed. The data of the patients were evaluated retrospectively from the electronic health records in the hospital database. Therefore, informed consent form could not be obtained from the patients. 31,151 individuals who applied to the hospital were included in the study. [25(OH)D] levels were determined according to the age, gender and seasons of the patients. While analyzing the data, patient names were kept confidential and ethical rules were followed. Patients over 75 years old were disabled in age group comparisons. Plasma [25(OH)D] levels were analyzed with ADVIA Centaur XP Immunoassay system using chemiluminescence method based on optimum sample processing and high efficiency. Serum [25(OH)D] level $<12 \mathrm{ng} /$ $\mathrm{mL}$ has been considered as serious deficiency, 12-20 ng/mL mild to moderate deficiency, $21-30 \mathrm{ng} / \mathrm{mL}$ insufficiency, $>30 \mathrm{ng} / \mathrm{mL}$ proficiency $(8,10)$.

\section{Statistical Analysis}

One-Way ANOVA, Kruskal-Wallis analyzes were performed using the SPSS 15.0 package program to determine the relationship between vitamin D and age, gender and seasons. Average and standard error values are given in descriptive statistics. $P<0.05$ value was considered significant.

\section{Results}

Age and gender status of patients coming from Siirt and neighboring provinces to Siirt Training and Research Hospital are divided into groups according to months and seasons, and descriptive statistics, mean and standard deviation values are given in tables. Demographic information and mean [25(OH)D] levels of the patients are given in Table 1. Considering the sex of the patients; it is seen that this study consists of 21,555 women and 9,596 men. When the average of $[25(\mathrm{OH}) \mathrm{D}]$ level of the patients was evaluated as total, it was found to be $15.96 \pm 0.08$ $\mathrm{ng} / \mathrm{mL}$ in women and $19.20 \pm 0.11 \mathrm{ng} / \mathrm{mL}$ in men. [25(OH)D] levels were statistically lower in females compared to males at $p<0.01$ significance level (Table 1). [25(OH)D] levels according to the age of the patients are given in Table 2. Average $[25(\mathrm{OH})$ D] level in patients aged 0-15 $(n=6,166) 20.59 \pm 0.14 \mathrm{ng} / \mathrm{mL}$, average $[25(\mathrm{OH}) \mathrm{D}]$ level in patients aged 16-30 $(n=10,791)$ $15.65 \pm 0.10$ Average of $[25(\mathrm{OH}) \mathrm{D}]$ level in patients with age 31$45(n=6,649) 16.28 \pm 0.14 \mathrm{ng} / \mathrm{mL}$, average 25 in patients aged 46-60 $(n=4,120)[25(O H) D]$ level was found to be $16.03 \pm 0.15$ $\mathrm{ng} / \mathrm{mL}$, and in patients aged 61-75 $(\mathrm{n}=2,597)$, the average level of $[25(\mathrm{OH}) \mathrm{D}]$ was $16.83 \pm 0.23$. As the age variable, as a result of the regression analysis, the $p$ value is $(p<0.05)$ statistically significant and it can be said that the vitamin $D$ value changes as the age progresses, especially at the highest levels in the 0-15 age group (Table 2). Kruskal-Wallis test was applied between 4 groups for seasonal differences. As a result of the test, statistical differences were seen between the seasons (Table 3). One-Way ANOVA test was used to test whether there is a relationship between vitamin $D$ and the moon. Post-hoc test was used to

Table 1. Demographic information of patients and average 25-hydroxyvitamin D levels

\begin{tabular}{|l|l|l|l|}
\hline Gender & $\mathbf{n}$ & Average $(\mathbf{n g} / \mathbf{m L})$ & $\mathbf{p}$ \\
\hline Woman & 21,555 & $15.96 \pm 0.08$ & \multirow{2}{*}{$p<0.01$} \\
\cline { 1 - 2 } Man & 9,596 & $19.20 \pm 0.11$ & \\
\hline \multicolumn{2}{|l}{ Data are given as mean and standard error } \\
\hline
\end{tabular}


determine in which months the difference was experienced Since the assumption of homogeneity cannot be provided, the application of variance analysis was not considered appropriate. For this reason, Kruskal-Wallis test was applied and the average values of the months are given (Table 4). Although there is no significant difference between the months of the test, it is possible to say that the vitamin $D$ is at the lowest levels in July

Table 2. 25-hydroxyvitamin D change according to the age of the patients

\begin{tabular}{|c|c|c|c|}
\hline Age group & $\mathbf{n}$ & $\begin{array}{l}\text { Average } \\
(\mathrm{ng} / \mathrm{mL})\end{array}$ & $p$ \\
\hline Group 1 & 6,166 & $20.59 \pm 0.14$ & \multirow{6}{*}{$\begin{array}{l}\text { Group 1-2, } p<0.01 \\
\text { Group 1-3, } p<0.01 \\
\text { Group 1-4, } p<0.01 \\
\text { Group 1-5, } p<0.01 \\
\text { Group 2-3, } p<0.05 \\
\text { Group 2-4, } p<0.05 \\
\text { Group 2-5, } p<0.01 \\
\text { Group 3-4, NS } \\
\text { Group 3-5, NS } \\
\text { Group 4-5, NS }\end{array}$} \\
\hline Group 2 & 10,791 & $15.65 \pm 0.10$ & \\
\hline Group 3 & 6,649 & $16.28 \pm 0.14$ & \\
\hline Group 4 & 4,120 & $16.03 \pm 0.15$ & \\
\hline Group 5 & 2,597 & $16.83 \pm 0.23$ & \\
\hline & & & \\
\hline
\end{tabular}

Data are given as mean and standard error, Group 1: 0-15 years, Group 2: 16-30 years, Group 3: 31-45 years, Group 4: 46-60 years, Group 5: 61-75 years

Table 3. Seasonal variation of patients' mean 25-hydroxyvitamin D levels

\begin{tabular}{|c|c|c|c|}
\hline Season & $\mathbf{n}$ & $\begin{array}{l}\text { Average } \\
\text { (ng/mL) }\end{array}$ & $\mathbf{p}$ \\
\hline Group 1 & 9,615 & $18.03 \pm 0.10$ & \multirow{4}{*}{$\begin{array}{l}\text { Group 1-2, } p<0.01 \\
\text { Group 1-3, } p<0.01 \\
\text { Group 1-4, } p<0.05 \\
\text { Group 2-3, } p<0.05 \\
\text { Group 2-4, } p<0.01 \\
\text { Group 3-4, } p<0.01\end{array}$} \\
\hline Group 2 & 7,937 & $13.32 \pm 0.13$ & \\
\hline Group 3 & 6,722 & $15.76 \pm 0.14$ & \\
\hline Group 4 & 6,877 & $19.68 \pm 0.13$ & \\
\hline
\end{tabular}

Data are given as mean and standard error, NS: Not significant, Group 1: Autumn, Group 2: Winter, Group 3: Spring, Group 4: Summer

Table 4. Average 25-hydroxyvitamin D levels by month

\begin{tabular}{|l|l|l|}
\hline Months & $\mathbf{n}$ & Average $(\mathbf{n g} / \mathbf{m L})$ \\
\hline January & 2,530 & $12.63 \pm 0.27$ \\
\hline February & 2,487 & $12.52 \pm 0.22$ \\
\hline March & 2,120 & $13.78 \pm 0.25$ \\
\hline April & 2,539 & $15.73 \pm 0.22$ \\
\hline May & 2,063 & $17.32 \pm 0.23$ \\
\hline June & 2,014 & $18.76 \pm 0.22$ \\
\hline July & 2,938 & $20.86 \pm 0.19$ \\
\hline August & 1,925 & $18.88 \pm 0.23$ \\
\hline September & 3,436 & $19.78 \pm 0.17$ \\
\hline October & 3,288 & $20.12 \pm 0.16$ \\
\hline November & 2,891 & $13.36 \pm 0.18$ \\
\hline December & 2,920 & $12.13 \pm 0.19$ \\
\hline \multicolumn{2}{|l|}{ Data are given as mean and standard error } \\
\hline
\end{tabular}

and August compared to July, August, September and October when the descriptive statistics are examined (Figure 1).

\section{Discussion}

Vitamin D deficiency, which is a global public health problem, is the most common in Northern Europe with $92 \%$ of the world. In Turkey emerges with a ratio of between 57-64\% $(11,12)$. It directly affects the level of vitamin $D$ in food and beverages, as well as external factors such as direct exposure to sunlight, clothing style, localization of the place of residence, air pollution, seasonal changes (13-17). In our study, vitamin D levels of patients who applied to Siirt Training and Research Hospital from Siirt and neighboring cities were analyzed retrospectively. It was found that vitamin D levels in women were statistically significantly lower compared to men (Table 1). Bolland et al. (18) examined vitamin D levels in 1,606 female healthy post-menopausal women living in New Zealand and 378 male patients of middle and advanced age. It is said that $73 \%$ of women and $39 \%$ of men are deficient in vitamin D (18). In their studies, Hekimsoy et al. (7) examined the vitamin D levels of 391 patients over 20 years of age living in the countryside and in the countryside. Overall, they found the mean of vitamin D levels to be $16.9 \pm 13.09 \mathrm{ng} / \mathrm{mL}$. They found that the deficiency in women was $78.7 \%, 66.4 \%$ more than men (7). In their study in Ankara, the mean vitamin D levels of 3,242 patients were determined to be $22.80 \pm 13.27$ $\mathrm{ng} / \mathrm{mL}$, and $47 \%$ of patients (50\% in women, $38 \%$ in men) $<20 \mathrm{ng} / \mathrm{mL}$ levels of vitamin D were detected (19). Studies have talked about the existence of vitamin $D$ levels similar to our results, and according to the data obtained, women have lower levels of vitamin D than men. Similarly, in our study, vitamin $D$ was found lower in women than men $(p<0.01)$. In the Siirt region, a lower vitamin D profile was observed in women compared to the men we thought to be related to bone mineralization status due to the high number of women

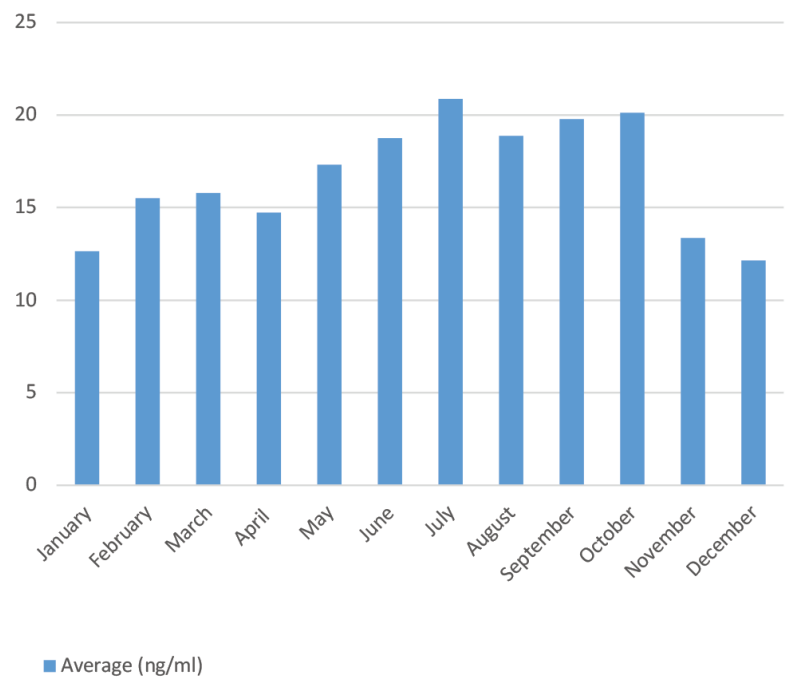

Figure 1. 25-hydroxyvitamin D levels by month 
wearing traditional and closed clothes and high fertility. At the same time, it is not possible to see a significant difference between the months according to the seasonal condition, but it is possible to say that the vitamin D is lower in December and November compared to October and July when looking at the descriptive statistics.

Brustad et al. (13) measured the level of vitamin D in those living in the northern parts of the country in Norway. In those who spent the previous summer in the south of the country, they found vitamin D higher in winter measurements compared to those in the north of the country. In the study of Barger-Lux and Heaney (20), [25(OH)D] level was measured $122 \mathrm{nmol} / \mathrm{L}$ at the end of summer and $74 \mathrm{nmol} / \mathrm{L}$ at the end of the winter in men exposed to more sun in general such as construction, landscaping and farming. Whereas those with $[25(\mathrm{OH}) \mathrm{D}]$ levels lower than $75 \mathrm{nmol} / \mathrm{L}$ at the end of winter were $104 \mathrm{nmol} / \mathrm{L}$ at the end of the summer, the average of those above $75 \mathrm{nmol} / \mathrm{L}$ was found as $154 \mathrm{nmol} / \mathrm{L}$ (21). The highest vitamin D levels are reached especially in the summer months, and as far as the parallels go up in northern sphere countries, very little vitamin $D$ is synthesized in November-March periods $(16,17)$. Ghannam et al. (22) they found $24.1 \mathrm{nmol} / \mathrm{L}$ in women between the ages of 30-40 in Saudi Arabia and $22.8 \mathrm{nmol} / \mathrm{L}$ (normal $>20$ $\mathrm{nmol} / \mathrm{L}$ ) in women between the ages of 20-30, Meddeb et al. (23) with a similar study, they found $35.07 \mathrm{nmol} / \mathrm{L}$ in closed clothing in January-March in Tunisia and $42.5 \mathrm{nmol} / \mathrm{L}$ in closed clothing $(22,23)$. In Australia, vitamin D level was found below the normal value $(22.5 \mathrm{nmol} / \mathrm{L})$ in $80 \%$ of closed clothing (24). Güzel et al. (25) in Adana province, they measured [25(OH) D] level of extremity and uncovered women and women with closed clothing including hands and faces, $53.9 \mathrm{ng} / \mathrm{mL}$ and $33.1 \mathrm{ng} / \mathrm{mL}$, respectively, in August-September (25). In the study in the young adult group in India, vitamin D was found to be $38.7 \mathrm{nmol} / \mathrm{L}$ in women with open arms and forearms, and $47.5 \mathrm{nmol} / \mathrm{L}$ in rural women with more body areas living in the villages (26). Considering the data obtained in this study, it is understood that $[25(\mathrm{OH}) \mathrm{D}]$ levels are at low levels. It has been observed that $[25(\mathrm{OH}) \mathrm{D}]$, which is low in winter and spring, is high in summer and autumn exposed to intense rays of the sun, but is lower than the desired levels in all four seasons. This low level of vitamin D may be associated with the absence of almost any vitamin $D$ synthesis in the winter season and inadequate vitamin $D$ intake with foods. In order to regulate the low vitamin D profile, vitamin supplements, various nutritional supplements, abundant sun and stay away from stress may be recommended. Oxidative stress, which underlies all metabolic diseases, also negatively affects vitamin levels. Therefore, combating oxidative damage can be an effective method over vitamin D. In a study conducted in rats, it is understood that the original new synthetic compounds are effective on oxidative stress pathways and regulate malondialdehyde and vitamins (27). Effective and continuous solutions should be sought with these and similar studies.

\section{Study Limitations}

There is a need for extensive studies in which the major limitation of this study has been determined the links between the vitamin $\mathrm{D}$ profile and metabolic bone diseases.

\section{Conclusion}

In this region where our study is conducted, vitamin D deficiency also occurs in the summer period, in this region where women wear clothes that cover the parts other than the face and hands, and that it is worn indoors according to relatively western provinces in men. The main reason for the difference in our study groups is that the highest vitamin D synthesis during the year is in the summer season, clothing differences affect this and the sun exposure continues in the autumn. In recent years, interest in the potential benefits of vitamin $D$ has been increasing. This situation has arisen from the interpretation of the results obtained from osteoporotic fracture studies, vitamin D and calcium metaanalyzes. Serum vitamin D levels include calcium, phosphorus, fibroblast growth factor-23, parathormone, etc. It is regulated by and kept in homeostatic balance. The data obtained in this study will require new and more comprehensive studies on the relationship of low vitamin D profile of the region and metabolic bone diseases such as osteomalacia and osteoporosis, as well as cancer, diabetes, multiple sclerosis and cardiovascular diseases.

\section{Ethics}

Ethics Committee Approval: The study was conducted in Siirt Training and Research Hospital with the approval of the Siirt University Non-Invasive Clinical Research Ethics Committee (decision no: 2019/09.03, date: 26.12.2019).

Informed Consent: Informed consent form could not be obtained from the patients.

Peer-review: Internally peer-reviewed.

\section{Authorship Contributions}

Concept: N.Ö.A., Design: N.Ö.A., O.Ö., Data Collection or Processing: N.Ö.A., O.Ö., Analysis or Interpretation: N.Ö.A., O.Ö., Literature Search: N.Ö.A., Writing: N.Ö.A., O.Ö.

Conflict of Interest: No conflict of interest was declared by the authors.

Financial Disclosure: The authors declared that this study received no financial support.

\section{References}

1. Cutolo M, Otsa K. Vitamin $D$, immunity and lupus. Lupus 2008;17:6-10.

2. Bouillon R, Marcocci C, Carmeliet G, Bikle D, White J, DawsonHughes B. Skeletal and Extraskeletal Actions of Vitamin D: Current Evidence and Outstanding Questions. P Endocr Rev 2019;1;40:1109-51.

3. Gouni-Berthold I, Krone W, Berthold HK. Vitamin D and cardiovascular disease. Curr Vase Pharmacol 2009;7:414-22.

4. Hewison M. Vitamin D and the immune system: New perspectives on an old theme. Endocrinol Metab Clin North Am 2010;39:36579. 
5. Renehan AG, Roberts DL, Dive C. Obesity and cancer: Pathophysiological and biological mechanisms. Arch Physiol Biochem 2008;114:71-83.

6. Johnson AR, Milner JJ, Makowski L. Way of inflammation: Metabolism accelerates inflammatory traffic in obesity. Immunol Rev 2012;249:218-38.

7. Hekimsoy $Z$, Dinç $G$, Kafesçiler $S$, Onur E, Güvenç $Y$, Pala $T$, et al. Vitamin $D$ status among adults in the Aegean region of Turkey. BMC Public Health 2010;10:782-8.

8. Canadian Agency for Drugs and Technologies in Health. Vitamin D Testing in the General Population: A Review of the Clinical and Cost-Effectiveness and Guidelines. Ottawa (ON); 2015.

9. Halicioglu O, Aksit S, Koc F, Akman SA, Albudak E, Yaprak, I, et al. Vitamin $D$ deficiency in pregnant women and their neonates in spring time in western Turkey. Paediatr Perinat Epidemio 2012;26;53-60.

10. Telo S, Kaman D, Akgöl G. Alteration of Vitamin D Levels According to Age, Gender and Seasons in Elazığ. Firat Med J 2017;22:29-33.

11. Gois P, Ferreira D, Olenski S, Seguro A. Vitamin D and Infectious Diseases: Simple Bystander or Contributing Factor. Nutrients 2017;9:651.

12. Büyükdere $Y$, Ayaz $A$. Evaluation of the association between tuberculosis and vitamin d: current approaches. Sakarya Med 2019;9:565-73.

13. Brustad M, Alsaker E, Engelsen O, Aksnes L, Lund E. Vitamin D status of middle-aged women at $65-71$ degrees $N$ in relation to dietary intake and exposure to ultraviolet radiation. Public Health Nutr 2003;7:327-35.

14. Chapuy MC, Preziosi P, Maamer M, Arnaud S, Galan P, Hercberg $S$, et al. Prevalance of vitamin D insufficiency in an adult normal population. Osteoporos Int 1997;7:439-43.

15. Kull M, Kallikorm R, Tamm A, Lember M. Seasonal variance of 25$(\mathrm{OH})$ vitamin $\mathrm{D}$ in the general population of Estonia, a Northern European country. BMC Public Health 2009;9:22

16. Pasco JA, Henry MJ, Kotowicz MA, Sanders KM, Seeman E, Pasco $J R$, et al. Seasonal periodicity of serum vitamin $D$ and hormone bone resorption, and fractures: The geelong osteoporosis study. J Bone Miner Res 2004;19:752-8.
17. Van der MIA, Ponsonby AL, Engelsen O, Pasco JA, McGrath JJ, Eyles DW, et al. The high prevalance of vitamin D insufficiency across Australian populations is only partly explained by season and latitude. Environ Health Perspect 2007;115:1132-9.

18. Bolland MJ, Grey AB, Ames RW, Mason BH, Horne AM, Gamble $\mathrm{GD}$, et al. The effects of seasonal variation of 25-hydroxyvitamin $D$ and fat mass on a diagnosis of vitamin D sufficiency. Am J Clin Nutr 2007;86:959-64

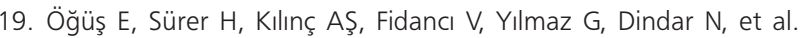
Evaluation of vitamin $\mathrm{D}$ levels by months, sex and age. Ankara Med J 2015;15:1-5

20. Barger-Lux MJ, Heaney RP. Effects of above average summer sun exposure on serum 25-hydroxyvitamin D and calcium absorption. J Clin Endocrinol Metab 2002;87:4952-6.

21. Şahin Z, Kumbasar F, Yiğit S, Yaman V, Turhan B, Kartal I. The effect of dressing style on vitamin D level in winter. Turk J Osteoporos 2011;17:6-9

22. Ghannam NN, Hammami MM, Bakheet SM, Khan BA. Bone mineral density of the spine and femur in healthy Saudi females: relation to vitamin D status, pregnancy, and lactation. Calcif Tissue Int 1999;65:23-8

23. Meddeb N, Sahli H, Chahed M, Abdelmoula J, Feki M, Salah H, et al. Vitamin D deficiency in Tunisia. Osteoporos Int 2005;16:180-3.

24. Grover SR, Morley R. Vitamin D deficiency in veiled or dark-skinned pregnant women. Med J Aust 2001;175:251-2.

25. Güzel R, Kozanoglu E, Güler-Uysal F, Soyupak S, Sarpel T. Vitamin $D$ status and bone mineral density of veiled and unveiled Turkish women. J Womens Health Gend Based Med 2007;115:1132-9.

26. Harinarayan CV, Ramalakshmi T, Prasad UV, Sudhakar D. Vitamin D status in andhra pradesh: a population based study. Indian J Med Res 2008;127:211-8.

27. Alayunt NO, Karatepe M, Parlak AE, Ulas M, Turkoglu S, Daştan $S D$, et al. The effects of some bis-1, 2, 4-triazole containing aminomethyl derivatives on MDA levels and vitamins in tissues of rats. J Chem Soc Pak 2019:41:707-13. 